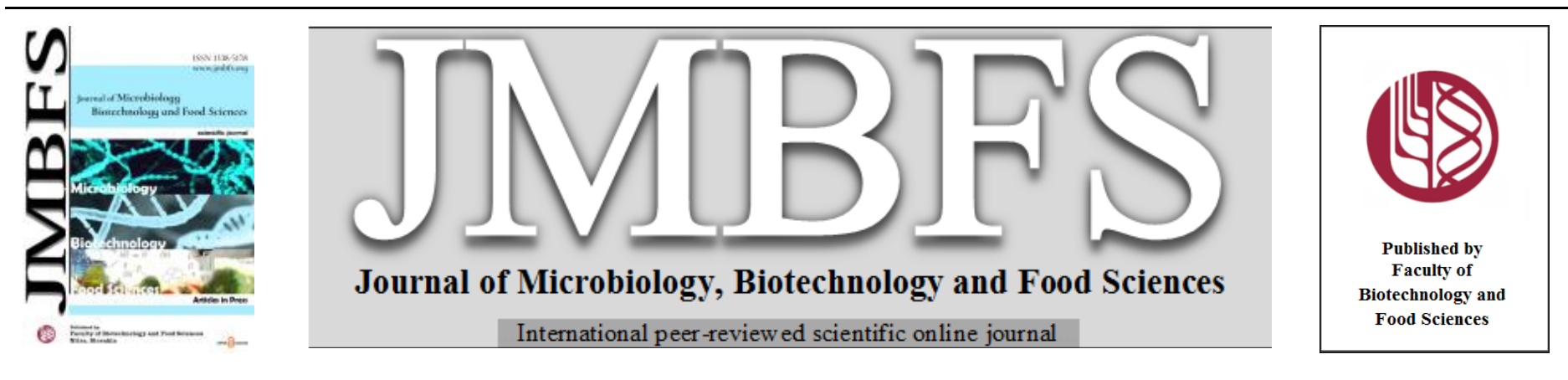

\title{
HEMATOLOGICAL AND SEROLOGICAL PARAMETERS FOR DETECTION OF COVID-19
}

\author{
Abduladheem Turki Jalil *1,6, Mustafa Tareq Shanshool ${ }^{2}$, Saja Hussain Dilfy ${ }^{3}$, Marwan Mahmood Saleh ${ }^{4}$, Ahmed AbdulJabbar \\ Suleiman $^{5}$
}

\author{
$\operatorname{Address(es):~}$ \\ ${ }^{1}$ Faculty of Biology and Ecology, Yanka Kupala State University of Grodno, Grodno, Belarus . \\ ${ }^{2}$ Laboratory Medical Technician, Ministry of Health and Environment, Baghdad, Iraq. \\ ${ }^{3}$ Medical Laboratory Technique, Kut University College, kut, Wasit, Iraq,52001. \\ ${ }^{4}$ College of Applied Sciences/University of Anbar, Anbar-Iraq. \\ ${ }^{5}$ College of Science-Biotechnology Department-University of Anbar, Anbar-Iraq. \\ ${ }^{6}$ College of technical engineering, The Islamic University, Najaf, Iraq.
}

*Corresponding author: abedalazeem799@gmail.com

https://doi.org/10.55251/jmbfs.4229

\section{ARTICLE INFO}

Received 17. 1. 2021

Revised 21. 8. 2021

Accepted 3. 9. 2021

Published 1. 2. 2022

Short communication

open $\odot$ access

\begin{abstract}
Coronavirus disease (COVID-19) appeared as outbreak in 2019 in Wuhan, China. It has been classified as pandemic disease and more severe than predicted; with infections already recorded in a variety of countries. This study aims to confirm the COVID-19 infection through the following tests: hematological, C-reactive protein (CRP). Samples were collected from the infected patients and sent to the National Flu Center (Central Public Health Laboratory) for COVID-19 (positive or negative) diagnosis by the RT-PCR technique. In this study, sixty five of COVID-19 patients and twenty five of healthy control samples male and female were collected in Iraq. There are significant differences in the parameters of the hematological markers for patients in comparing with the control group and no significant differences were observed in $\mathrm{Hb}$ when $\mathrm{RBC}$ and GRAN percent rise in patients relative to the control group with $\mathrm{P}=0.0395$ and $\mathrm{P}=0.0354$ respectively comparing with the control group. White blood cells (WBC), Lymphocyte (LYM\%), Platelets (PIT), monocyte (Mid\%), hematocrit (HCT), mean corpuscular volume (MCV), mean corpuscular hemoglobin (MCH), mean platelet volume (MPV), plateletcrit (PCT) was drop dramatically in patients compared to control group. Fifty-one of patients for whom the test was given exhibited a positive (CRP) result. Likewise, the results showed that few patients were negative to CRP test. The Hematological parameters levels (HCT, MCV, MCH, Pelt, WBC, LYM, Mid, MPV, PCT) decreased, but Hb, RBC, GRAN\% increased. C-reactive protein test showed a positive result in $85 \%$ of patients which can be considered an indicator for predicting severity infection with COVID-19.
\end{abstract}

Keywords: COVID-19, Coronavirus, CRP, SARS-CoV-2, Pandemic Disease

\section{INTRODUCTION}

Previously, COVID-19 known as the 2019 novel coronavirus (2019-nCoV), the World Health Organization announced on 30 January 2020 an emergency in public health (Sohrabi et al., 2019). Dramatic steps were placed in place to the stop virus spreading. The coronavirus is extremely infectious and causes pneumonia in 2019 (Yi et al., 2020). It was first reported in Wuhan, Hubei Province, China, in December 2019 and then accompanied by an outbreak in Hubei Province and other sections of the world. There is no authorized simple and effective treatment at this period (Cui et al., 2019). Several reports have identified the clinical characteristics of newly infected coronavirus (SARS-CoV-2) pneumonia (COVID-19) patients showing a higher lymphocyte neutrophil ratio (LNR) in serious patients. Several studies including travel-related and non-travel-related incidents from China and other countries, have been reported in leading international science and medical journals. Many of these experiments have tried to resolve research questions like patterns and consequences, possible risk factors and health (Rodriguez-Morales et al., 2020). Experimental and imaging findings; while longitudinal experiments and meta-analysis typically include randomized controlled trials aimed at offering a more precise assessment of cancer or disease risk factor effects; there has also been considerable use of synthesized empirical research, especially over the past several decades. Possible forms of transmission involve droplets of water, touch, fomites and the fecal-oral path (Driggin et al., 2020). There is currently no definitive proof of airborne SARS-CoV-2 transmission, although historical experience suggested that aerosol-producing procedures can be transmit SARS CoV-2, usually intubation with the trachea. Like other respiratory infections, it was deemed contagious when patients become symptomatic but asymptomatic individuals also can transmit this novel virus. The early results indicate that the transmissibility of SARS-CoV-2 is low, with a simple reproductive amount of about 2 (Atri et al., 2020). SARS-CoV-2 human to human transmission occurs primarily between members in family, relatives, and close friends. According to reports, 31.3 percent of recent non-resident patients visited Wuhan, and 72.3 percent of patients who interacted with people visited Wuhan (Xu et al., 2020). China's National Health Commission reported that COVID-19 transmitted to $3.8 \%$ of health workers. Conversely, SARS-CoV and MERS-CoV had been identified primarily via nosocomial transmission (Jalil, 2020). In MERS-CoV cases, health care staph infections accounted for 33-42 percent of SARS cases and the most common routes of infection were a patient transmission (62-79 per cent). SARSCoV-2 's primary transmitter channel is due to close contact with intermediate hos animals or wildlife intake (Yeo et al., 2020). This study aims to confirm that COVID-19 infection can be detected through hematological and C-reactive protein testing.

\section{MATERIAL AND METHODS}

\section{Sample collection}

Samples were collected from (65) patients from both male and female, infected with COVID-19 at the Al Furat General Hospital in Baghdad, Iraq by Nasopharyngeal and Throat swabs. These swabs were transferred into a transport media virus (TMV) and sent to the National Flu Center (NFC) and a central public health laboratory in Baghdad for COVID 19 diagnosis by using an rRT-PCR technique as recommended by CDC. Also, the control group included 25 healthy people of similar ages and genders. 


\section{Hematologic tests}

The analyzer (DIAGON D-Cell60 hematological) used to measure CBC parameters. Besides, Diaton-D-Diluent was replaced with a portion of the firs dilution. After the second sample dilution, the impedance particle analysis was then introduced to measure red blood cell counts (RBC) and thrombocyte counts (PLT) A Lysing Reagent was added (Diaton-Lyse-D) to the rest of the first dilution for measuring Hemoglobin (HGB), lymphocyte counts (LYM), white blood cell counts (WBCs), and GRAN, mid-percent, HCT,

MCV, MCH, MPV, PCT (Ike et al., 2010).

\section{Crp latex tests}

CRP-Latex Test is a fast slide agglutination method based on a serum modification of the latex fixing method, developed to directly detect and semi-quantify Creactive protein $(\mathrm{CRP})$. The test was performed by testing with anti-human CRP antibodies, a suspension of latex particles coated against unknown serum. The presence of a visible agglutination in the tested samples indicates an increase in CRP levels above the reference interval's upper limit (CRP-Latex, kit).

\section{Statistical analysis}

Statistical analysis was carried out by SPSS Version 17 (SPSS, Inc., Chicago, IL, USA), mean \pm standard deviation (SD) was calculated. T-test was used to verify essential variations between the classes. The statistically significant $\mathrm{P}$ value at $\mathrm{P} \leq 0.05$ was considered in the past

\section{Ethical considerations}

All subjects consented to be included in this study. The research was reviewed and approved through the local Committee of Study.

\section{RESULTS}

Table 1 Assessment of hematological markers and control group in COVID-19 infections.

\begin{tabular}{l|c|c|c}
\hline \multirow{2}{*}{ Tests } & \multicolumn{2}{|c}{ Groups } & \multirow{2}{*}{ P-value } \\
\cline { 2 - 3 } & Patients & Control & \\
\hline $\mathrm{Hb}(\mathrm{g} \backslash \mathrm{dl})$ & $13.04 \pm 0.191$ & $13.04 \pm 0.351$ & N.S. $^{* *}$ \\
\hline RBC $\left(* 10^{12} \backslash \mathrm{L}\right)$ & $4.94 \pm 0.101 \mathrm{~A}$ & $4.52 \pm 0.146 \mathrm{~b}$ & 0.0395 \\
\hline WBC $\left(* 10^{9} \mathrm{~L}\right)$ & $7.04 \pm 0.441$ & $7.34 \pm 0.433$ & N.S. \\
\hline LYM \% & $22.3 \pm 1.63 \mathrm{~B}$ & $30.4 \pm 1.71 \mathrm{a}$ & 0.0107 \\
\hline GRAN \% & $67.0 \pm 1.77 \mathrm{~A}$ & $59.9 \pm 1.64 \mathrm{~b}$ & 0.0354 \\
\hline PLT $\left(* 10^{9} \mathrm{~L}\right)$ & $231 \pm 10.9 \mathrm{~B}$ & $336 \pm 24.6 \mathrm{a}$ & $0.0001>$ \\
\hline Mid \% & $6.18 \pm 0.233 \mathrm{~B}$ & $8.03 \pm 0.862 \mathrm{a}$ & 0.0047 \\
\hline HCT \% & $30.1 \pm 0.712 \mathrm{~B}$ & $45.4 \pm 1.20 \mathrm{a}$ & $0.0001>$ \\
\hline MCV $(\mathrm{fL})$ & $82.0 \pm 1.39 \mathrm{~B}$ & $90.7 \pm 1.39 \mathrm{a}$ & 0.0016 \\
\hline MCH $(\mathrm{pg})$ & $29.7 \pm 1.28$ & $30.8 \pm 0.453$ & N.S. \\
\hline MPV $(\mathrm{fL})$ & $8.58 \pm 0.228$ & $9.27 \pm 0.412$ & N.S. \\
\hline PCT \% & $0.154 \pm 0.007 \mathrm{~B}$ & $0.202 \pm 0.013 \mathrm{a}$ & 0.0035 \\
\hline
\end{tabular}

* Means \pm Standard Error.

** N.S.: Non-Significant

a, b, c: means in the same Row with different superscripts differ significantly at probability value $(\mathrm{P} \leq 0.05)$.

There are significant differences in the parameters of the hematological markers for patients when compared with the control group at $\mathrm{P} \leq 0.05$ (Table 1) and no significant differences were observed in $\mathrm{Hb}$ when compared with the control group (Figure 1.A). However, RBC Increase in patients with $\mathrm{P}=0.0395$ (Figure 1.C), a slight decrease in WBC (Figure 1.C), decrease in LYM\% with $\mathrm{P}=0.0107$ (Figure 1.D), Increasing in GRAN\% with $\mathrm{P}=0.0354$ was found (Figure1.D), while a decrease in PIT with 0.0001 $>\mathrm{P}$ (Figure1. B), mid\% with $\mathrm{P}=0.0047$ (Figure1.E), HCT with $0.0001>\mathrm{P}$ (Figure 1.A) and MCV with $\mathrm{P}=0.0016$ (Figure 1.A), a slight decrease in MCH (Figure 1.A), MPV (Figure 1.E), and PCT (Figure 1.F) with $\mathrm{P}=0.0035$.

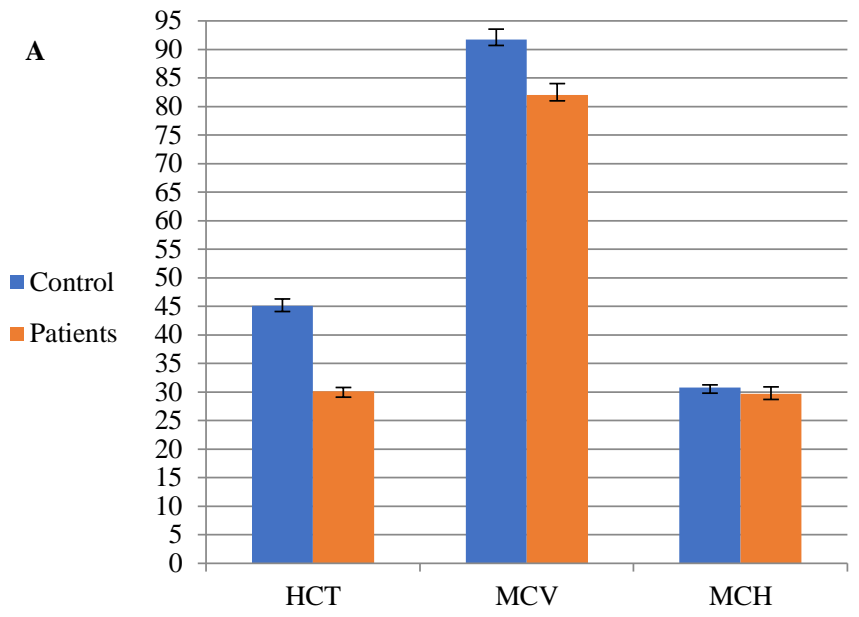

B

\section{Platelet}
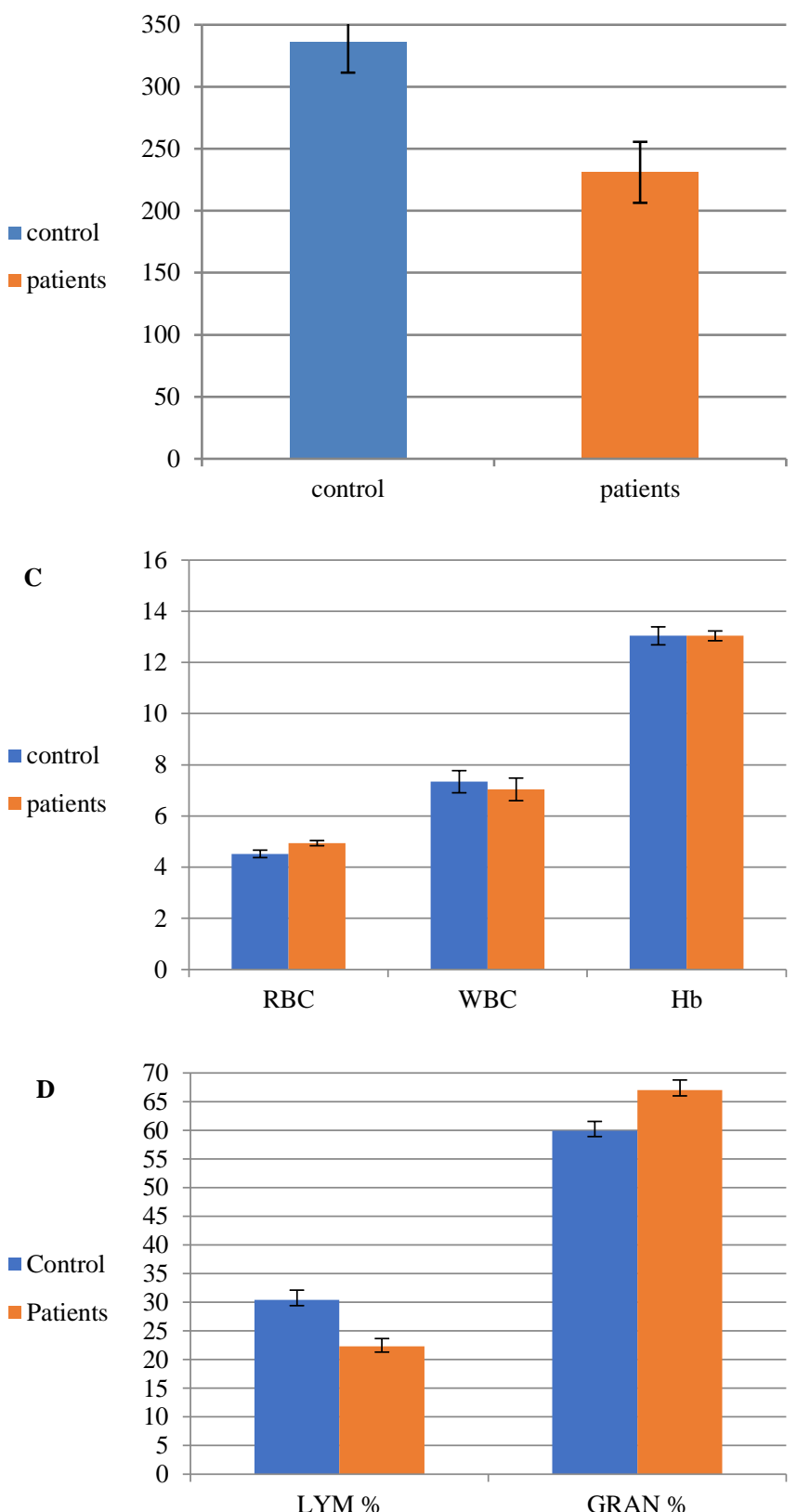

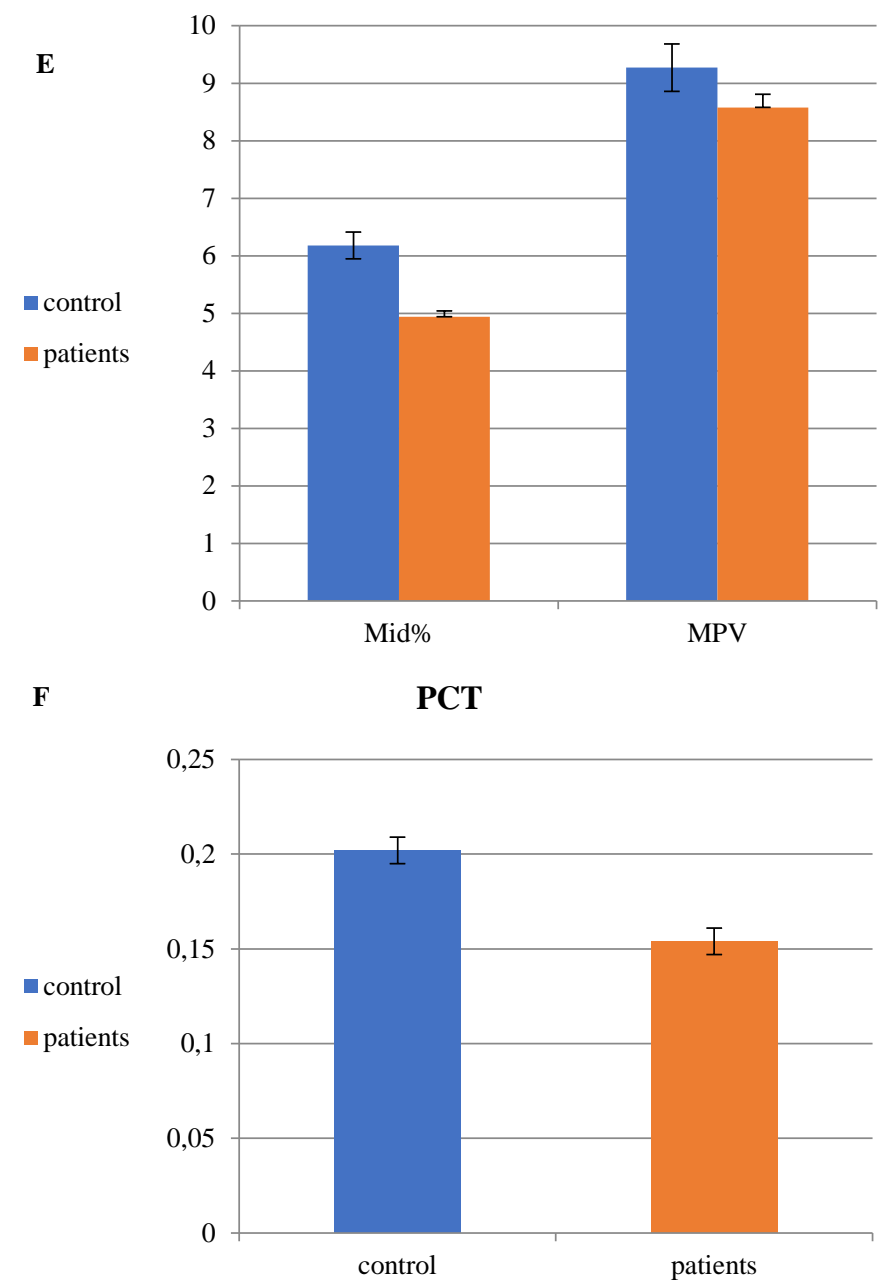

Figure 1 A- distribution HCT (\%), MCV (fL), and MCH (pg) among COVID-19 infection. B- distribution PLT $\left(* 10^{9} / \mathrm{L}\right)$ among COVID-19 infection. Cdistribution $\mathrm{RBC}\left(* 10^{12} \mathrm{~L}\right)$, WBC $\left(* 10^{9} \mathrm{~L}\right)$, and $\mathrm{Hb}(\mathrm{g} \backslash \mathrm{dl})$ among COVID-19 infection. D- distribution LYM (\%) and GRAN (\%) among COVID-19 infection. E- distribution Mid (\%) and MPV (fL) among COVID-19 infection. F- Distribution PCT (\%) among COVID-19 infection.

The results of the CRP test showed that most patients (85\%) exhibited a positive (CRP) results, while $15 \%$ of them showed a negative test (CRP), as shown in Figure 2.

\section{CRP}

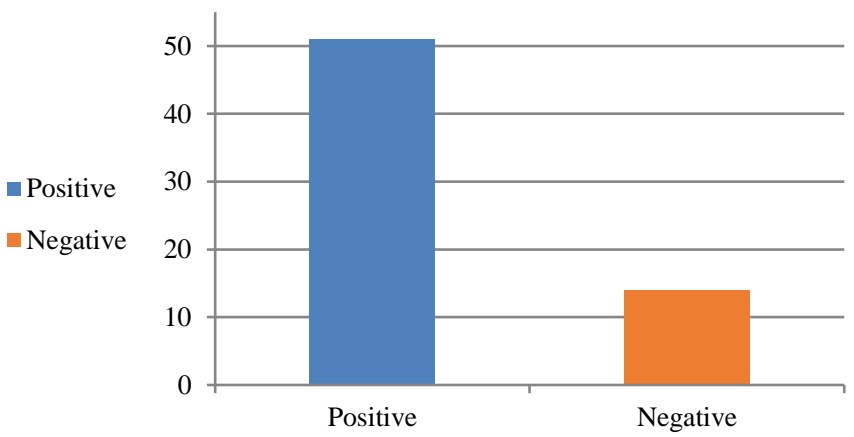

Figure 2 Distribution C-reactive protein (Mg/L) among COVID-19 infection.

\section{DISCUSSION}

Previous findings showed that the most common symptom of Covid-19 and Cough in both sexes and ages is extreme throat, though diarrhea was not common, accompanied by fever, and some patients had no symptoms at all (Kim et al., 2020). Coronaviruses are a large family of viruses found in several distinct groups of animals; including camels, goats, cats and bats. Rarely, coronaviruses in animals will spread to human and then transmission among human, such as MERS, SARS and now SARS-CoV-2 (Mackay and Arden, 2015). There are decreases in WBCs among patients when compared with the control group (Figure1.C) and this result is consistent with those of Huang et al. (2020) and Fan et al. (2020). Only one patient with severe leukopenia (WBC $<2 \times 109 / \mathrm{L})$ in 19 patients $(29.2$ percent) were observed with leukopenia (WBC $<4$ x 109 / L). Our findings are similar to a standard range line in several cases. This research publishes findings for adult COVID-19 patients with hematopoietic and infection associated biomarkers. In the current study, (Figure1.D) Lymphopenia is common in COVID-19 patients; indicating an impairment of the immune system during SARS-CoV-2 infection. It is found that LYM decreased in most patients and it was below the normal ratio, this result agrees with the result of Gao et al. (2020) and Zhou et al., (2020) Also, the results are consistent with the study of Fan $\boldsymbol{e t}$ al. (2020) regarding that the platelets are low in patients. The current study revealed no decrease in hemoglobin in patients (Figure1.A) and this outcome coincides with the results of Hadadi et al. (2020). A slight rise in red blood cells and GRAN (Figure1.C andFigure1.D) is also observed, in contrast with the finding of Liu et al. (2020). The PCT result showed a decrease in patients, unlike the result of Fan et al. (2020). Among the 140 patients, PCT increased respectively. In the SG, the proportion of patients with elevated IL-6, CRP and PCT levels was significantly higher than the MG. Nevertheless, in contrast with healthy individuals, HCT, MCV, and Mid\% reported relatively low p-value (Table 1), which may be affected by pathological conditions. This may be of clinical significance for diagnosing COVID-19. The association between platelet and disease was observed (Table 1); this was consistent with the study of Cheng et al. (2020) which revealed an important correlation between low platelet count and COVID-19 patients. Our findings are consistent with those of Luo et al. (2020) since the values of HCT, MCV, MCH and MPV COVID-19 patients decreased as compared to the control group. Therefore, a simple blood test is helpful in detecting false/ negative rRT-PCR tests but can also be used as a costeffective and usable in developing countries, otherwise identifying potential COVID-19 patients with rRT-PCR reagents and/or specialist laboratories (Ferrari et al., 2020; (Saleh et al.,2020). CRP is an inflammatory agent used to detect multiple diseases and morbidities and to track them. In extreme COVID-19 cases, the degree of inflammation-related CRP and its concentration are not affected by such factors such as age, gender and physicality health (Bilgir $\boldsymbol{e t}$ al., 2015).

CRP levels may promote phagocytosis and activate the complement, thus cleaning up pathogenic microorganisms that invade the organism may be used for early detection of CRP levels (Warusevitane et al., 2016), and elevated CRP rates in extremely pneumonia cases. This is an important index for identifying and assessing serious infectious pulmonary diseases (Chalmers $\boldsymbol{e t}$ al., 2019). Testing with Matsumoto also showed the levels of CRP increased as the disease progressed with severe pneumonia. CRP rates have been positively linked with lung lesions and the extent of the disease. This indicates that CRP levels at the early COVID19 may indicate lung lesions and the severity of the disease. Liu et al. (2020) reported that CRP increased by 65 percent of COVID-19 patients. The current COVID-19 study indicates that rates of CRP are substantially different between the deceased party and the living community, which may act as a possible prognostic marker (Ruan et al., 2020) (Zhang et al., 2020). CRP is well patient severity correlated with COVID-19 patient symptoms and is therefore suitable for evaluating patient conditions along with other clinical findings.

\section{CONCLUSION}

The study was conducted on 90 people included 65 patients infected with Covid19 and 25 healthy persons as a control group, the following biomarkers can be adopted for diagnosis of the virus and the adoption of these tools, the levels of the Hematological parameters decrease (HCT, MCV, MCH, Pelt, WBC, LYM, Mid, MPV, PCT), and increase in ( $\mathrm{Hb}, \mathrm{RBC}, \mathrm{GRAN} \%)$. C-reactive protein test showed a positive result in $85 \%$ of patients which will be considered an indicator for predicting severity infection with COVID-19.

Acknowledgments:We are pleased to extend our thanks to, Dr. Jasib Al-Hijam (director of Baghdad / karkh health department) and Dr. Muhammad Ibrahim Yassin, Director of Al Furat General Hospital and Laboratory Officer (Wassan Khaled), and Dr. Muna Abdulghani (Assistant Professor in diagnostic imaging) for support and facilitating the task of research and our thanks and appreciation to all the medical staff at $\mathrm{Al} \mathrm{Furat} \mathrm{General} \mathrm{Hospital.}$

\section{REFERENCES}

Sohrabi C, Alsafi Z, O'Neill N, Khan M, Kerwan A, Al-Jabir A, Iosifidis C, Agha R, 2019. World Health Organization declares global emergency: A review of the novel coronavirus (COVID-19). International Journal of Surgery. 2020 Feb 26. https://doi.org/10.1016/j.ijsu.2020.02.034

Yi Y, Lagniton PN, Ye S, Li E, Xu RH, 2020. COVID-19: what has been learned and to be learned about the novel coronavirus disease. International journal of biological sciences.;16(10):1753.https://dx.doi.org/10.7150\%2Fijbs.45134

Cui HT, Li YT, Guo LY, Liu XG, Wang LS, Jia JW, Liao JB, Miao J, Zhang ZY, Wang L, Wang HW, 2020. Traditional Chinese medicine for treatment of coronavirus disease 2019: a review. Traditional Medicine Research. Feb 9;5(2):6573. https://dx.doi.org/10.12032/TMR20200222165 
Rodriguez-Morales AJ, Cardona-Ospina JA, Gutiérrez-Ocampo E, VillamizarPeña R, Holguin-Rivera Y, Escalera-Antezana JP, Alvarado-Arnez LE, BonillaAldana DK, Franco-Paredes C, Henao-Martinez AF, Paniz-Mondolfi A, 2020 Clinical, laboratory and imaging features of COVID-19: A systematic review and meta-analysis. Travel medicine and infectious disease. Mar 13:101623.https://doi.org/10.1016/j.tmaid.2020.101623

Driggin E, Madhavan MV, Bikdeli B, Chuich T, Laracy J, Biondi-Zoccai G, Brown TS, Der Nigoghossian C, Zidar DA, Haythe J, Brodie D, 2020 Cardiovascular considerations for patients, health care workers, and health systems during the COVID-19 pandemic. Journal of the American College of Cardiology. May 12;75(18):2352-71. https://doi.org/10.1016/j.jacc.2020.03.031

Atri D, Siddiqi HK, Lang J, Nauffal V, Morrow DA, Bohula EA, 2020. COVID19 for the cardiologist: a current review of the virology, clinical epidemiology, cardiac and other clinical manifestations and potential therapeutic strategies. JACC: Basic to Translational Science. Apr 10.https://doi.org/10.1016/j.jacbts.2020.04.002

Xu J, Zhao S, Teng T, Abdalla AE, Zhu W, Xie L, Wang Y, Guo X, 2020. Systematic comparison of two animal-to-human transmitted human coronaviruses: SARS-CoV-2 and SARS-CoV. Viruses. Feb;12(2):244 https://doi.org/10.3390/v12020244

Jalil AT, 2020. COVID-19 MOST AFFECTED AGE GROUPS AND LETHALITY IN EUROPE. Glob. j. public health med. Jun.;2(SP1):179-84 https://doi.org/10.37557/gjphm.v2iSP1.51

Yeo C, Kaushal S, Yeo D, 2020. Enteric involvement of coronaviruses: is faecaloral transmission of SARS-CoV-2 possible? The lancet Gastroenterology \& hepatology. Apr 1;5(4):335-7.https://doi.org/10.1016/S2468-1253(20)30048-0

Ike SO, Nubila T, Ukaejiofo EO, Nubila IN, Shu EN, Ezema I, 2010. Comparison of haematological parameters determined by the Sysmex KX-2IN automated haematology analyzer and the manual counts. BMC clinical pathology. Dec 1;10(1):3. https://doi.org/10.1186/1472-6890-10-3

Kim ES, Chin BS, Kang CK, Kim NJ, Kang YM, Choi JP, Oh DH, Kim JH, Koh B, Kim SE, Yun NR, 2020. Clinical course and outcomes of patients with severe acute respiratory syndrome coronavirus 2 infection: a preliminary report of the first 28 patients from the Korean cohort study on COVID-19. Journal of Korean medical science. Apr 6;35(13).https://dx.doi.org/10.3346\%2Fjkms.2020.35.e142 Mackay IM, Arden KE, 2015. Middle East respiratory syndrome: an emerging coronavirus infection tracked by the crowd. Virus research. Apr 16; 202:60-88.

https://doi.org/10.1016/j.virusres.2015.01.021

Huang C, Wang Y, Li X, Ren L, Zhao J, Hu Y, Zhang L, Fan G, Xu J, Gu X, Cheng Z, 2020. Clinical features of patients infected with 2019 novel coronavirus in Wuhan, China. The lancet. Feb 15;395(10223):497-506. https://doi.org/10.1016/S0140-6736(20)30183-5

Fan BE, Chong VC, Chan SS, Lim GH, Lim KG, Tan GB, Mucheli SS, Kuperan $\mathrm{P}$, Ong KH, 2020. Hematologic parameters in patients with COVID-19 infection. American journal of hematology. Jun;95(6): E131-4. https://doi.org/10.1002/ajh.25774

Gao Y, Li T, Han M, Li X, Wu D, Xu Y, Zhu Y, Liu Y, Wang X, Wang L, 2020. Diagnostic utility of clinical laboratory data determinations for patients with the severe COVID-19. Journal of medical virology. Mar 17 https://doi.org/10.1002/jmv.25770

Zhou F, Yu T, Du R, Fan G, Liu Y, Liu Z, Xiang J, Wang Y, Song B, Gu X, Guan L, 2020. Clinical course and risk factors for mortality of adult inpatients with COVID-19 in Wuhan, China: a retrospective cohort study. The lancet. Mar 11.

https://doi.org/10.1016/S0140-6736(20)30566-3

Hadadi A, Mortezazadeh M, Kolahdouzan K, Alavian G, 2020. Does recombinant human erythropoietin administration in critically ill COVID-19 patients have miraculous therapeutic effects? Journal of Medical Virology. Apr 8. https://doi.org/10.1002/jmv.25839

Liu Y, Du X, Chen J, Jin Y, Peng L, Wang HH, Luo M, Chen L, Zhao Y, 2020. Neutrophil-to-lymphocyte ratio as an independent risk factor for mortality in hospitalized patients with COVID-19. Journal of Infection. Apr 10 https://doi.org/10.1016/j.jinf.2020.04.002

Cheng Z, Lu Y, Cao Q, Qin L, Pan Z, Yan F, Yang W, 2020. Clinical features and chest CT manifestations of coronavirus disease 2019 (COVID-19) in a singlecenter study in Shanghai, China. American Journal of Roentgenology. Mar 14:16. https://doi.org/10.2214/AJR.20.22959

Luo E, Zhang D, Luo H, Liu B, Zhao K, Zhao Y, Bian Y, Wang Y, 2020. Treatment efficacy analysis of traditional Chinese medicine for novel coronavirus pneumonia (COVID-19): an empirical study from Wuhan, Hubei Province, China. Chinese Medicine. Dec; 15:1-3.https://doi.org/10.1186/s13020-020-00317-X

Ferrari D, Motta A, Strollo M, Banfi G, Locatelli M, 2020. Routine blood tests as a potential diagnostic tool for COVID-19. Clinical Chemistry and Laboratory Medicine (CCLM). Apr 16;1(ahead-of-print). https://doi.org/10.1515/cclm-20200398

Saleh, M. M., Jalil, A. T., Abdulkereem, R. A., \& Suleiman, A. A. Evaluation of Immunoglobulins, CD4/CD8 T Lymphocyte Ratio and Interleukin-6 in COVID19 Patients. Turkish Journal Of Immunology, 8(3), 129-134. https://doi.org/10.25002/tji.2020.1347
Bilgir O, Bilgir F, Calan M, Calan OG, Yuksel A, 2015. Comparison of pre-and post-levothyroxine high-sensitivity c-reactive protein and fetuin-a levels in subclinical hypothyroidism Clinics.

Feb;70(2):97-101 https://doi.org/10.6061/clinics/2015(02)05

Warusevitane A, Karunatilake D, Sim J, Smith C, Roffe C, 2016. Early diagnosis of pneumonia in severe stroke: clinical features and the diagnostic role of Creactive protein. PloS one. Mar 3;11(3): e0150269. https://doi.org/10.1371/journal.pone.0150269

Chalmers S, Khawaja A, Wieruszewski PM, Gajic O, Odeyemi Y, 2019. Diagnosis and treatment of acute pulmonary inflammation in critically ill patients: The role of inflammatory biomarkers. World Journal of Critical Care Medicine. Sep 11;8(5):59.https://dx.doi.org/10.5492\%2Fwjccm.v8.i5.59

Liu F, Li L, Xu M, Wu J, Luo D, Zhu Y, Li B, Song X, Zhou X, 2020. Prognostic value of interleukin-6, C-reactive protein, and procalcitonin in patients with COVID-19. Journal of Clinical Virology. Apr 14:104370. https://doi.org/10.1016/j.jcv.2020.104370

Ruan Q, Yang K, Wang W, Jiang L, Song J, 2020. Clinical predictors of mortality due to COVID-19 based on an analysis of data of 150 patients from Wuhan, China. Intensive care medicine. May;46(5):846-8. https://doi.org/10.1007/s00134-020 05991-X

Zhang JJ, Dong X, Cao YY, Yuan YD, Yang YB, Yan YQ, Akdis CA, Gao YD, 2020. Clinical characteristics of 140 patients infected with SARS-CoV-2 in Wuhan, China. Allergy. Feb 19.https://doi.org/10.1111/all.14238 